\title{
West-Centric Divide, Global Health, and Postcolonial Intervention
}

\author{
Amit Prasad \\ Department of Sociology, University of Missouri-Columbia/ prasada@missouri.edu
}

"West urges curb on Indian clinic's untested treat-
ment."1 This statement of The Guardian about an
embryonic stem cell therapy clinic in Delhi that I
have been studying for the last five years presents
a very familiar claim. I have heard such invocations
of the West even by my students and colleagues
and they are commonly used by politicians as well
as academics. Yet, in spite of its familiarity, the
statement is also intriguing. What does the utter-
ance "West urges" mean? Is it a set of representa-
tives of the West - people, institutions, or countries
- who are urging? As one reads this newspaper
article one can see the denotative reference shift-
ing from "Western researchers have called for" to
"Experts in Britain expressed concern."
Who is included or excluded from the category of the West seems obvious. The Guardian article quotes Stephen Minger and Alison Murdoch, two university-based British scientists, Simon Best of the UK Biotechnology Association, and an editorial of the British Medical Journal to express its concerns not just in relation to this particular clinic, but to the wider practice of overseas stem cell therapy "stretching from Mexico to China. "The particular clinic, which is the focus of the article, thus becomes a metonym for the Global South and the non-West ("stretching from Mexico to China"). And in doing so the article replicates a common trope through which the Global South and the non-West is seen/shown as the source and site of the problem for unproven stem cell therapies, in the media reports as well as academic writings. Discursive situating of this clinic in the
Global South/non-West is further reinforced in The Guardian article in its short profile of the Director of this particular clinic, Geeta Shroff, that states: "Hanging from her office walls are Indian medical diplomas, training certificates from Asian research institutes, and a picture of her with India's prime minister Manmohan Singh, who is a friend of the family."

In this commentary I analyze The Guardian article neither to de-legitimize its claim nor to suggest that it is biased. My concern is simply how the utterance "West urges" is performatively enacted to present a West-centric divide. One could argue, following Bruno Latour (1993), that we should not see the work of 'purification' (e.g. that of the category of the West) as separate from the work of 'translation' - through which mixtures and hybrids are produced. If we focus only on the former, we, as Latour further reminds us, remain condemned to a modernist critical stance that simply recreates and reinforces the purifications and misses the proliferating hybrids.

The Guardian article that I quoted above does indeed present traces of such 'translations.' The article, for example, discusses the experiences of a "Briton with motor neuron disease" who received treatment at this clinic. The name of this patient (Jaspal Toor) indicates that he is possibly of Indian origin. In fact, the name of the author of the article (Randeep Ramesh) suggests that he too is possibly of Indian origin. One can complicate the story even further by mapping the associations of diverse human and non-human actors that must 
have made not only the writing of this article possible, but also provision of stem cell therapy at the clinic in Delhi. In short, if we map the historical, geopolitical, and social processes that constitute the 'West' (and its 'other') we can show how the category hides, and also appropriates, translations and hybridity.

Exploration and description of the hybrids is arguably an effective analytical strategy to move beyond the dualist divides of not just West/ non-West, but also many other binaries, such as nature/culture and so on (Latour, 1993). For postcolonial science studies, particularly under the influence of Warwick Anderson, a focus on hybrids, multiplicities, and translations has become one of the most important approaches. ${ }^{2}$ Suman Seth, building on the approaches of Anderson and other postcolonial theorists, calls for "postcolonial history of colonial science and medicine" to investigate "not the blurring of extant boundaries but the socially imbricated, tentative, and complex coming-into-being of the categories and binaries" (Seth, 2017: 77). Intrinsic to Seth's call is further historical and empirical investigations in order to unravel the multi-layered and situated roles of the binaries as well as their erasures and transgressions.

My commentary weaves together and responds to the above-mentioned postcolonial science studies concern with those expressed in this special issue titled "STS and Global Health: Critique and Complicity."The special issue is aimed at bridging several boundaries - between STS and global health, activist and academic engagement, critique and complicity, Global North/Global South, etc. The editorial (Sariola et al.) through a fictional dialogue between Dr. STS, Dr. Activist, and Dr. Epi(demiology) unravels the underlying intersections, in spite of the seemingly unbridgeable tensions, between the fields of STS, activism, and epidemiology. Sariola, Engel, Kingori, and Montgomery show how the overlapping interests of the three domains and their representatives could (should) result in collaborations. "Just think about it, we could start something together, we could apply for funding to do just that," they write through the fictional voice of Dr. Epi addressing Dr. STS and Dr. Activist. Such bridging, for the editorial collective, does not gloss over the hierarchies between the fields and the attendant anxieties: The activist, for example, remains "worried that her position could become more exploited." The articles in the special issue similarly underline and trouble the implicit boundaries that undergird a range of global health discourses and practices.

In this commentary, I aim to contribute to the concerns raised in this special issue and postcoIonial science studies' engagement with binaries and hybrids by analyzing discursive emplotment of West-centric binaries in relation to a fast growing sector of global health, namely overseas stem cell therapy. Specifically, drawing on Edward Said (1979), I argue that we need to explore imaginative history and geography that inevitably have a component that remains latent, which, nevertheless, is central to the articulations of the Westcentric divide. I focus on the discursive framing of overseas stem cell therapy because, unlike most other sectors of global health, overseas stem cell therapy complicates the West-centric divide. A significant section of the experimental subjects in this case are middle-class (often also white) patients from the West. This situation prompts an anxiety that finds expression in a complex discursive emplotment of West-centric divide. In the first section I situate my approach in relation to postcolonial engagements with hybrids, translations, and circulations of science, technology, and medicine. And then, in the concluding section, I return to The Guardian article to further analyze its enactment of West-centric divide, particularly the use of the phrase "miracle cures" for stem cell therapy at the clinic in Delhi.

\section{Situating Hybrids and West-centric Divide}

"The more articulations develop with human and non-human actors," Warwick Anderson argues following Latour, "the more stable and robust the object becomes. Society, nature, and geography are thus the outcomes, rather than the causes, of these mobilisations, translations and enrolments" (Anderson, 2009: 391). Anderson calls for a focus on 'conjugated subjects' rather than 'subjugated knowledges.' Conjugated subject, for him, "is meant to hint at postcolonial hybridity and heterogeneity, suggesting a more complicated state 
of affairs" (Anderson, 2009: 389). The broader goal, as Anderson argued in a co-authored article with Vincanne Adams, is "to situate technoscience within differing global, or at least multi-sited, imaginaries, using postcolonial perspectives" (Anderson and Adams, 2008).

Suman Seth (2017), acknowledging the role of "postcolonial science studies and postcolonial theory more generally" in "dismantling, troubling, and blurring the categories and binaries that are taken to characterize colonial modes of thought and governance," suggests "an additional approach":

One that does not reify them [binary logics of colonialism] but, rather asks about the changing contexts in which, and the means by which, such boundaries and dichotomies were produced and maintained in the first place (Seth, 2017: 64).

"The postcolonial history of colonial science," Seth adds, "must not be merely resuscitated; it must be re-formed" (Seth, 2017: 64). I agree with Seth and applaud him for carefully and deftly bringing together a diverse set of postcolonial studies to further echo the call for postcolonial approaches in not just history of science and medicine, as he suggests, but also in other disciplines. Anderson and Harding, among others, have been highlighting the lack of traction of postcolonial analytics and methods within science and technology studies (STS) and have forcefully made the case, albeit differently, for integration of postcolonial approaches within mainstream STS (see e.g. Anderson, 2009; Harding, 2011a). It is in the spirit of re-forming postcolonial science studies I make this intervention.

Let me return to Seth's article, in particular his analysis of an exchange between Itty Abraham and Warwick Anderson. Seth rightly points to Abraham's concern with "postcolonial as a mode of analysis...linked to a fixed site of irreducible knowledge claims," which thereby "articulates an ontology that ties knowledge to location as a singular and essential quality of place" (Abraham, 2006: 210; Seth, 2017). That is, postcolonial critique cannot limit itself simply to reversing the binaries, wherein the non-West (and the West) continues to have essentialized relationship to knowledges and practices. The issue for Abraham, however, is not only of empirical/material and epistemological suturing of knowledge and place. It is not just that "[c]ritiques of globalization and an attention to transnational technoscientific movement were in; and essentialized ethnosciences were out" (Seth, 2017: 70). Abraham's broader concern is failure "to see the power of modern science in political terms, as ideology" (Abraham, 2006: 210). More broadly, how should postcolonial science studies (and STS in general) investigate the role and impact of say West-centric binaries beyond their manifest empirical/material expressions in the making of scientific knowledge(s)? And the concern is not simply in relation to what would postcolonial science studies miss as a result of ignoring the role of ideology, but also our own slippages, as analysts, into the binaries that we wish to transgress and move beyond.

My concerns are similar to those of Abraham, but I am wary of using the concept of ideology, because of its dependence upon dualist separation between, to use Marxist terminology, 'super-structure' and 'base,' even when these two are shown as coeval and co-constitutive. I prefer the Foucauldian concept of discourse and its articulation through dispositif - arrangement of people, things, spaces, norms, etc. (Foucault, 1979; Foucault, 1994; Said, 1979; Butler, 1990). In particular, I would like to draw upon Said's concepts of imaginative history and geography in the articulations of the discourse of Orientalism and West-centrism (Said, 1979). Imaginative geography and history, Said (1979) writes, "help the mind to intensify its own sense of itself by dramatizing the distance and difference between what is close to it and what is far away." Consequently, in Orientalist narratives (fictional or non-fictional), "there is something more than what appears to be purely positive knowledge" (Said, 1979: 55).

Said's formulation of imaginative history and geography as fusing of fantasies, myths, and desires with "positive knowledge" will hardly come as a surprise to STS scholars. STS scholarship has consistently highlighted socially constructed nature of scientific facts and posited symmetry between not just facts and beliefs, but also true and false beliefs (Bloor, 1991; Latour, 1987; Haraway, 1991; Shapin and Schaffer, 1985; Knorr 
Cetina, 1981). Latour (1999: 306) uses a neologism - factish - to signify "types of action that do not fall into the comminatory choice between fact and belief." "The two [fact and belief]," he argues, "have a common element of fabrication" (Latour, 1999: 306). The concern for Latour is "to take seriously the role of actors in all types of activities" (Latour, 1999: 306).

In spite of such radical re-orientation in our understanding of the interplay between facts and fetishes, reality and belief, STS rarely, if ever, investigates this interplay in the constitution of discourses and subjects. Hence, to return to The Guardian article, with STS tools we can unravel how stem cell therapy is provided and the role of the social in constituting knowledge and practices at the clinic and in India. We can also argue that West-centric divide presents a false binary. However, in doing so we would ignore, on the one hand, how such a divide operates through excess (i.e. more than its empirical/material manifestations) and, on the other, the continued power of this discursively constructed West-centric divide in geo-biopolitical control (i.e. disciplining of individuals and population beyond the nationstate). In relation to the latter, i.e. geo-biopolitical control, we would need to excavate how its power is articulated not simply through, for example, the law, but also through a chain of significations.

Homi Bhabha points out how Said's elaboration of latent (desires, myths, fantasies, etc.) and manifest ("positive" knowledge in literature, history, anthropology, etc.) re-presentations uncovers Orientalism as "a static system of 'synchronic essentialism"' (Bhabha, 1994: 102). Bhabha (1994), focusing on the inherent instability of the Orientalist discourse as a result of "diachronic forms of history and narrative," unravels the ambivalence of the colonial discourse and stereotypes. He, thus, draws our attention to "the mode of representation of otherness" and its biopolitical implications (Bhabha, 1994: 97). My concern is similar, though, I analyze the mode of representation of otherness somewhat differently. I follow a deconstructive-empirical approach (Prasad, 2014). Deconstruction of, for example, Euro/West-centrism provides discursive clearing, which instead of attempting to transcend Euro/West-centric divides puts them under "erasure," thereby opening up possibilities for empirical/historical investigation of circulations of knowledge that simultaneously highlight and challenge the power of such discourses. The phrase "imperial technoscience" signals this inherent tension that, I think, best describes the situation that we are in at present, within and outside the academia.

Let me briefly illustrate my approach with an example and thereafter, in the next section, I will further elaborate it in the context of overseas stem cell therapy. Recent historicizations of modern Western science, including its purported origin in the Scientific Revolution, are important interventions that have reoriented our understanding of "origin" and circulation of science (see e.g. Shapin, 1996; Elshakry, 2008; Elshakry, 2010; Raj, 2007). Indeed, as Steven Shapin (1996: 1) puts it: "There was no such thing as the Scientific Revolution". Shapin (1996), thereafter, goes on to historically situate the transformations in seventeenth century Europe. My concern is different, but complementary. The issue for me is how are we to understand and analyze the invocation of the Scientific Revolution as a historical project, for example by Herbert Butterfield (1957), at the time of dramatic (post) colonial transition, when European powers were losing their prized colonies? ${ }^{3}$ Moreover, isn't the discursive emplotment of the Scientific Revolution a mode of representation of 'otherness'? The goal then becomes, along with historicization of the Scientific Revolution, analysis of its West-centric 'translations' and circulations through difference and deference - diffêrance in Derridean terms (Derrida, 1981a; Derrida, 1978; Derrida, 1981b). This West-centric emplotment of 'otherness' finds expression not only in, for example, diffusion (Basalla, 1967) and dependency (Rostow, 1960) theories, but also in everyday scientific practices and their histories (Prasad, 2014). The Guardian report, with whose analysis I started this commentary, exemplifies a West-centric emplotment of 'otherness.' I further deconstruct this emplotment in the following.

\section{"Miracle Cures," West-Centric Divide, and Stem Cell Therapy in India}

The headline of The Guardian article that I quoted and analyzed earlier is blunt: "Row over doctor's 'miracle cures'."' Interestingly, the word miracle is 
not mentioned in the rest of the article. Moreover, presentation of the phrase miracle cures within quotation marks signals the author's (and the newspaper's) ambivalence. And yet the deployment of the word miracle is significant, particularly since it has been ubiquitous in characterizations of stem cell therapy at this clinic. On May 21, 2012 $\mathrm{CNN}$, for example, had carried a primetime documentary on this clinic that was titled "Selling a Miracle."

I have also read and heard patients use the term miracle to characterize the changes that they witnessed in their bodies as a result of embryonic stem cell therapy at this clinic. As one patient put it: "This feels quite miraculous." ${ }^{5}$ According to another patient, "[w]hen I first moved my toes, I was blown away... The doctors in Australia told me I would never walk again, but now I actually think I will be able to - without calipers some day. ${ }^{\prime \prime}$ In fact, The Guardian article also quotes a patient, who after a month of stem cell injections at this clinic experienced significant changes: "'I can sit up, feel sensation in my legs. I could not lift my legs, now I can take a few steps,' she said." The clinic and many of its patients, however, present therapy at this clinic not as outside science, but as the outside of science - the frontier with which present state of scientific research will catch up.

The term miracle used in The Guardian article and also in other reports, thus, embodies ambivalence. Indeed, as Jacalyn Duffin (2009) shows through an examination of 1,400 cases, which Roman Catholic Church recognized in canonization, most miracles pertain to medical care. A necessary feature "for an event to qualify as miraculous," Duffin argues, is that "it must remain unexplained by science" (Duffin, 2009: 5). The Guardian report is certainly not making a case for Shroff's canonization. Geeta Shroff, the Director of the embryonic stem cell therapy clinic, is not seeking canonization either. She wishes to be recognized as a scientist and in the last two years she has published more than forty papers documenting clinical outcomes. Embryonic stem cell therapy at this clinic, nevertheless, has been marked by criticism and ambivalence and it remains to be seen whether and to what extent publication of clinical outcomes will alter that in the future (Prasad, 2015; Prasad, 2016).
One can of course empirically investigate the associations of human and non-human actors, which cut across West/non-West divide, in the provision of stem cell therapy. I, however, do not wish to dwell here into how therapy is provided at this clinic. My concern in this commentary is limited to unraveling the discursive emplotment of West-centric divide and to highlight that any analysis of stem cell therapy at this clinic cannot be simplistically extricated from this emplotment. I must clarify I am not suggesting that ethical, juridical, and biomedical concerns in relation to stem cell therapy at this or other clinics in India should not be raised or that they are necessarily biased. I also do not wish to argue that all invocations of miracle in relation to therapy at this clinic are similar and express a West-centric divide. It is, nonetheless, important to map how latent and manifest Euro/West-centrism suffuses re-presentations of therapy at this clinic and, more broadly, stem cell therapies in India/non-West.

Invocation of the term miracle, very similar to what Derrida shows for pharmakon, springs "up from without" and does not "have any definable virtue of its own" (Derrida, 1981a: 102). The discursive emplotment of miracle, as is evident in The Guardian article, remains ambivalent because stem cell therapy at this clinic troubles the "accepted" (Western and modern) boundary between science and miracle. How are we to understand and characterize the changes that patients have claimed as a result of therapy at this clinic? The deployment of the term miracle is aimed at purging such therapies, as outside science and not as the outside of science. And it does so through a chain of significations that create and reinforce a West-centric divide. The excess in the invocation of miracle, thus, has to be read through "a certain displacement of the series" (Derrida, 1981a: 104). A 60 Minutes, Australia, report on Shroff's clinic, titled "Chasing a Miracle," for example, started with the claim: "On the ancient streets of Delhi, a city more accustomed to mystic healing than $21^{\text {st }}$ century medicine, a Brisbane mother is seeking out a modern-day miracle." ${ }^{\prime 8}$

In short, claims of miracle cures do not simply have denotative reference. Rather, such claims acquire meaning and discursive force as a part of a chain of significations. And in the process this 
chain of significations discursively frames overseas stem cell therapy through the trope of "gullible dupe and guileless maverick" (Bharadwaj, 2012: 312; Prasad, 2015). However, we have to be careful and not analyze these stereotypical constructions of stem cell therapies in non-Western countries such as India simply as "false images." The excess and ambivalence of, for example, the term miracle, which has been deployed in relation to "unproven" stem cell therapies not just in this clinic but also other such clinics in the Global South/non-West, are crucial for the very articulation of the Westcentric divide. And the discursive emplotment of such a divide undergirds a geo-biopolitical strategy that is signaled through the phrase "West urges."

'Otherness,' discursively constructed through a chain of significations, can, particularly in the absence of an international law, force national governments to take action. In The Guardian article "the top civil servant in India's health ministry," for example states: "'We have our concerns and worries about Dr Shroff's work."' Such discursive constructions of 'otherness' have been far more effective in instituting geo-biopolitical control with regard to, for example, medical transcription 'outsourcing' (Prasad and Prasad, 2012). However, in spite of fervent calls for the enactment of a specific law to regulate stem cell therapies, neither has India enacted such a law as yet, nor have stem cell therapies in the Indian clinics stopped. We need to situate such calls for juridical regulation in the societal context (Jasanoff, 2005; Jasanoff, 2011; Tiwari and Raman, 2014) and also highlight their genealogical links to colonial construction of the non-West as a "zone of lawlessness" (Benton, 2010; Prasad, 2017). And in doing so it becomes even clearer how any analysis of stem cell therapy in India/non-West without a deconstruction of latent and manifest re-presentations of Westcentric divide, advertently or inadvertently, risks slipping into the same binary. 


\section{References}

Abraham I (2000) Landscape and Postcolonial Science. Contributions to Indian Sociology 34: 163-187.

Abraham I (2006) The Contradictory Spaces of Postcolonial Techno-Science. Economic and Political Weekly 41: 210-217.

Anderson W (2002) Postcolonial Technoscience. Social Studies of Science 32: 643-658.

Anderson W (2009) From Subjugated Knowledge to Conjugated Subjects: Science and Globalisation, or Postcolonial Studies of Science? Postcolonial Studies 12: 389-400.

Anderson W (2012) Asia as Method in Science and Technology Studies. East Asian Science, Technology and Society: An International Journal 6: 445-451.

Anderson W and Adams V (2008) Pramoedya's Chickens: Postcolonial Studies of Technoscience. In: Hackett E, Amsterdamska O, Lynch M and Wajcman J (eds) The handbook of science and technology studies. Cambridge, MA: The MIT Press, pp. 181-204.

Basalla G (1967) The Spread of Western Science Science 156: 611-622.

Benton L (2010) A Search for Sovreignty: Law and Geography in European Empires, 1400-1900, New York: Cambridge University Press.

Bhabha H (1994) The Location of Culture, NewYork: Routledge.

Bharadwaj A (2012) Enculterating Cells: The Anthropology, Substance, and Science of Stem Cells. Annual Review of Anthropology 41: 303-317.

Bloor D (1991) Knowledge and Social Imagery, Chicago: University of Chicago Press.

Butler J (1990) Gender Trouble, New York: Routledge.

Butterfield H (1957) The Origins of Modern Science, New York: The Free Press.

Derrida J (1978) Writing and Difference, Chicago: University of Chicago Press.

Derrida J (1981a) Dissemination, Chicago: University of Chicago Press.

Derrida J (1981b) Positions, Chicago: University of Chicago Press.

Duffin J (2009) Medical Miracles: Doctors, Saints, and Healing the Modern World, New York: Oxford University Press.

Elshakry M (2008) Knowledge in Motion: The Cultural Politics of Modern Science Translations in Arabic. Isis 99: 701-730.

Elshakry M (2010) When Science Became Western: Historiographical Reflections. Isis 101: 98-109.

Foucault M (1979) Discipline \& Punish: The Birth of the Prison, New York: Vintage Books.

Foucault M (1994) The Birth of the Clinic, New York: Vintage.

Haraway D (1991) Simians, Cyborgs, and Women: The Reinvention of Nature, New York: Routledge.

Harding S (1994) Is Science Multicultural? Challenges, Resources, Opportunities, Uncertainties. Configurations 2: 301-330.

Harding S (1998) Is Science Multicultural? Postcolonialism, Feminisms and Epistemologies, Bloomington, IN: Indiana University Press.

Harding S (2011a) Beyond Postcolonial Theory: Two Undertheorized Perspectives on Science and Technology. In: Harding S (ed) The Postcolonial Science and Technology Studies Reader. Durham, NC: Duke University Press, pp. 1-31.

Harding S (2011b) The Postcolonial Science and Technology Studies Reader. Durham, NC: Duke University Press. 
Jasanoff S (2005) Designs on Nature: Science and Democracy in Europe and the United States, Princeton, NJ: Princeton University Press.

Jasanoff S (2011) Introduction: Rewriting Life, Reframing Rights. In: Jasanoff S (ed) Reframing Rights: Bioconstitutionalism in the Genetic Age. Cambridge, MA: MIT Press, pp. 1-27.

Knorr Cetina K (1981) The Manufacture of Knowledge: An Essay on the Constructivist \& Contextual Nature of Science New York: Pergmon Press.

Latour B (1987) Science in Action: How to Follow Scientists and Engineers through Society, Cambridge, MA: Harvard University Press.

Latour B (1993) We Have Never Been Modern, Cambridge, MA: Harvard University Press.

Latour B (1999) Pandora's Hope: Essay on the Reality of Science Studies, Cambridge, MA: Harvard University Press.

Nandy A (1990) Science, Hegemony and Violence: A Requiem to Modernity. Delhi: Oxford University Press.

Nandy A (1995) Alternative Sciences: Creativity and Authenticity in Two Indian Scientists, Delhi: Oxford University Press.

Prasad A (2014) Imperial Technoscience: Transnational Histories of MRI in the United States, Britain, and India, Cambridge, MA: MIT Press.

Prasad A (2015) Ambivalent Journeys of Hope: Embryonic Stem Cell Therapy in a Clinic in India. Health 19: 137-153.

Prasad A (2016) Discursive Contextures of Science: Euro/West-Centrism and Science and Technology Studies. Engaging Science, Technology and Society 2: 193-207.

Prasad A (2017) Biopolitical Excess: Techno-Legal Assemblage of Stem Cell Research in India. Science, Technology \& Society 22: 102-123.

Prasad A and Prasad S (2012) Imaginative Geography, Neoliberal Governmentality, and Colonial Distinctions: Docile and Dangerous Bodies in Medical Transcription Outsourcing. Cultural Geographies 19: 348-363.

Raj K (2007) Relocating Modern Science: Circulation and the Construction of Knowledge in South Asia and Europe, 1650-1900, New York: Palgrave Macmillan.

Rostow WW (1960) The Stages of Economic Growth, Cambridge, UK: Cambridge University Press.

Said E (1979) Orientalism, New York: Vintage.

Seth S (2017) Colonial History and Postcolonial Science Studies. Radical History Review 127: 63-85.

Shapin S (1996) The Scientific Revolution, Chicago: University of Chicago Press.

Shapin S and Schaffer S (1985) Leviathan and the Air-Pump: Hobbes, Boyle and the Experimental Life Princeton, NJ: Princeton University Press.

Tiwari S and Raman S (2014) Governing Stem Cell Therapy in India: Regulatory Vacuum or Jurisdictional Ambiguity. New Genetics and Society 33: 413-433.

Verran H (2001) Science and an African Logic, Chicago: University of Chicago Press.

Verran H (2002) A Postcolonial Moment in Science Studies: Alternative Firing Regimes of Environmental Scientists and Aboriginal Landowners. Social Studies of Science 32: 729-762. 


\section{Notes}

1 https://www.theguardian.com/science/2005/nov/18/stemcells.controversiesinscience, accessed 3.11.2017.

2 Postcolonial science studies constitute a very diverse field. The analytical and methodological approaches that are often included within this field, although broadly aimed at critiquing European colonialism and moving beyond Euro/West-centrism, differ markedly and may not even complement each other (see Abraham, 2000, 2006; Anderson, 2002, 2009, 2012; Harding, 1994, 1998, 2011 b; Nandy, 1990, 1995; Verran, 2001; 2002). In this article I am specifically focusing on a particular postcolonial approach that draws on Latourian and actor network theory tools and aims at excavating hybrids, translations and circulations.

3 Derrida (1978) writes, "one can assume that ethnology could have been born as a science only at the moment when a decentering had come about: at the moment when European culture... had been dis/ocated."

4 https://www.theguardian.com/science/2005/nov/18/stemcells.controversiesinscience, accessed 3.11.2017.

5 https://www.theguardian.com/world/2007/jun/03/health.india, accessed 5.11.2017.

6 http://www.couriermail.com.au/news/national/stem-cells-help-mum-walk/news-story/30a9844ef3257b 6daeca3e4f98ab9dd0, accessed 5.11.2017.

7 https://www.theguardian.com/science/2005/nov/18/stemcells.controversiesinscience, accessed 3.11.2017.

8 http://sci.rutgers.edu/forum/showthread.php?83783-Dr-Geeta-Shroef-Stem-Cell-research-patientresults-examined-at-Spinal-injuries-unit, accessed 5.11.2017. The original video and transcript of this 60 Minutes, Australia episode is no longer publicly available online. 